The fluid concept of ' $E U$ values' in the neighbourhood: a change of paradigm from East to South?

Nariné Ghazaryan

\title{
Introduction: Setting the Scene
}

Exporting European Union (EU) values has been a staple of the rhetoric of the European Neighbourhood Policy (ENP) since its early days in 2003. Values were to be promoted to and shared with all addressees of the policy, the list of which grew to cover a vast geographic area in the vicinity of the European Union, including both bordering and other countries. ${ }^{1}$ The ENP applies to the eastern and southern neighbours with varying intensities as some countries have seemingly advanced legally and politically in their cooperation with the EU, while others have not agreed on a basic framework of cooperation. ${ }^{2}$ In 2008 and 2009, a few years following its inception, EU neighbourhood policies were divided into regional flanks with the Eastern Partnership (EaP) and the Union for the Mediterranean (UfM). ${ }^{3}$

\footnotetext{
1 The following countries are addressees of the policy (some do not have immediate borders with the EU at present): Ukraine, Moldova, Belarus, Georgia, Armenia, Azerbaijan, Egypt, Algeria, Tunisia, Morocco, Israel, Occupied Palestinian Territories, Syria, Jordan, Lebanon, Libya.

${ }^{2}$ For instance no ENP Action Plans have been established with Belarus, Algeria, Libya or Syria as of June 2015.

3 Brussels European Council Conclusions, 19-20 June 2008, p. 19; Brussels European Council Conclusions, 13-14 March 2008, p. 19.
} 
Exporting EU values is a means to an end, i.e. the achievement of the wider policy objectives of securing a stable and safe zone around the post-2004 and 2007 enlargement borders of the EU. ${ }^{4}$ The underlying idea was that the more the neighbours replicated EU values, the safer and secure the EU would be. Ambitious in its scope, the policy aimed to integrate the neighbouring states to the EU in an extensive range of areas. ${ }^{5}$ In the absence of a membership agenda, the incentive of a deep and comprehensive free trade area has emerged gradually to motivate the willing neighbours in their efforts to emulate EU values as well as its institutions and practices.

${ }^{4}$ For the centrality of security considerations within the ENP see M. Smith and K. Webber, 'Political Dialogue and Security in the European Neighbourhood Policy: The Virtues and Limits of "New Partnership Perspective"” (2008) 13 EFAR 73, 81; W. Wallace,'Looking after the Neighbourhood: Responsibilities for the EU-25', Policy Papers No 4, Notre Europe 2003, 27; R. Zaiotti, 'Of Friends and Fences: Europe's Neighbourhood Policy and the 'Gated Community Syndrome' (2007) 29 European Integration 143, 149; M. Cremona and C. Hillion,'L'Union Fait La Force? Potential and Limitations of the ENP as an Integrated EU Foreign and Security Policy' in N. Copsey and A. Mayhew (eds), European Neighbourhood Policy: The Case of Europe, Sussex European Institute, SEI Seminar Papers Series Number 1, 2006, 20-44, 24.

5 COM (2003) 104 final, 11 April 2003, 5. On the legal aspects of ENP see $\underline{\text { M. Cremona, 'The European }}$ Neighbourhood Policy: More than a Partnership? in M. Cremona (ed), Developments in EU External Relations Law (OUP 2008); Cremona and Hillion, ibid.; B. Van Vooren, EU External Relations Law and the European Neighbourhood Policy: A Paradigm for Coherence (Routledge 2014); N. Ghazaryan, The European Neighbourhood Policy and the Democratic Values of the EU (Hart Publishing 2014). 
The application of the ENP conditionality both in the east and faced much criticism. ${ }^{6}$ Rather than considering EU values in the light of the policy conditionality, ${ }^{7}$ this paper aims to explore the normative agenda of this conditionality. Currently, Article 2 TEU offers a list of EU values such as freedom, democracy, equality, the rule of law and respect for human dignity and human rights, including minority rights. While this serves broadly as a signpost for the values to be promoted, it is worth analysing the content of these concepts. This chapter considers how the EU has shaped these values in its relations with Eastern and Southern neighbours.

At the outset of this debate, the EU might be expected to require a more stringent standard from the Eastern neighbourhood for two reasons. Firstly, the ENP was originally aimed at the Eastern neighbours, some of which, including Russia, were to be affected to a certain extent by the 2004 enlargement, and some of which were rather vocal about their aspirations for EU membership. Secondly, although the ENP intended to replace EU membership for the countries concerned, it

6 D. Kochenov, 'The ENP Conditionality: Pre-Accession Mistakes Repeated' in L. Delcour and E. Tulmets (eds), Pioneer Europe? Testing EU Foreign Policy in The Neighbourhood (Nomos 2008) 105-120, 116; A. Magen, 'The Shadow of Enlargement: Can the European Neighbourhood Policy Achieve Compliance?' Centre on Democracy, Development and the Rule of Law, Stanford Institute for International Studies, Working Paper No 68, August 2006, | 415; K.E. Smith, 'The Outsiders: The European Neighbourhood Policy’ (2005) 81 International Affairs 757, 765; N. Tocci, 'Can the EU Promote Democracy and Human Rights Through the ENP? The Case for Refocusing on the Rule of Law' in M. Cremona and G. Meloni (eds), The European Neighbourhood Policy: A New Framework for Modernisation?, EUI Working Papers, LAW 2007/21, 23-35, 31; M. Emerson, 'Is There to be a Real European Neighbourhood Policy?' in R. Youngs (ed), Global Europe: New Terms of Engagement, Foreign Policy Centre, UK, 2005, 15-22, 20; P. Seeberg, 'The European Neighbourhood Policy, Post-normativity and Pragmatism' (2010) 15 EFAR 663, 676; Ghazaryan, op.cit., 125-149; R.A. Del Sarto and T. Schumacher, 'From Brussels with Love: Leverage, Benchmarking, and the Action Plans with Jordan and Tunisia in the EU's Democratisation Policy' in S. Lavenex and F. Schimmelfennig (eds), Democracy Promotion in the EU's Neighbourhood: From Leverage to Governance (London, Routledge 2013), 48-71, 49.

${ }^{7}$ See Kochenov and Basheska in this volume. 
nevertheless did not entirely rule out such membership. Since there has been no membership rejection as in the case of Morocco in 1987, article 49 TEU allows any 'European' state to apply for membership upon fulfilling certain conditions. It was therefore legitimate to expect the EU to be stricter with European countries. However, this does not necessarily mean a that a strict standard is being imposed on all Eastern neighbours. ${ }^{8} \quad$ This chapter aims to explore the extent to which the values of the EU differ depending on the specific grouping of neighbours. In the first section, 'values' as established in the ENP foundational policy documents, as well as the Action Plans (APs) — the initial bilateral policy documents - are examined. The second section traces the projection of EU values in the multilateral frameworks of cooperation created following the geographic division in the policy and considers the effects that the Arab Spring revolutions have had on both policy flanks. The third section presents a comparison between the essential elements clauses in the latest and most important instruments of cooperation in the East - the newly established Association

\footnotetext{
${ }^{8}$ See for instance the comparison between the South Caucasian countries, Ghazaryan, op.cit.
} 
Agreements (AA) with Ukraine, Georgia and Moldova9 - and the Euro-Med Agreements in the South, some of which were concluded after the ENP had been inaugurated. ${ }^{10}$

\section{The EU values as set out in ENP documents and Action Plans}

The first ENP document contained an indication of the value dimension of this initiative. The 2003

Wider Europe Communication starts off by including democracy, respect for human rights and the rule of law within 'shared values' and, in a footnote, links these concepts to the Charter of Fundamental Rights. ${ }^{11}$ Not only did the Charter have no binding legal force at that time, but also its content, although relevant for democracy and the rule of law, could be characterised as a bill of

\footnotetext{
${ }^{9}$ Association Agreement between the European Union and the European Atomic Energy Community and their Member States, of the one part, and Georgia, of the other part [2014] OJ L261/4; Association Agreement between the European Union and the European Atomic Energy Community and their Member States, of the one part, and the Republic of Moldova, of the other part [2014] OJ L260/4; Association Agreement between the European Union and its Member States, of the one part, and Ukraine, of the other part [2014] OJ L161/5.

10 Euro-Mediterranean Agreement establishing an Association between the European Community and its Member States, of the one part, and the People's Democratic Republic of Algeria, of the other part [2005] OJ L 265/2; EuroMediterranean Agreement establishing an Association between the European Communities and their Member States, of the one part, and the Arab Republic of Egypt, of the other part [2004] OJ L304/39; Euro-Mediterranean Agreement establishing an Association between the European Communities and their Member States, of the one part, and the Hashemite Kingdom of Jordan, of the other part [2002] OJ L129/3; Euro-Mediterranean Agreement establishing an association between the European Communities and their Member States, of the one part, and the State of Israel, of the other part [2000] OJ L147/3; Euro-Mediterranean Agreement establishing an association between the European Communities and their Member States, of the one part, and the Kingdom of Morocco, of the other part [2000] OJ L 070/2; Euro-Mediterranean Agreement establishing an association between the European Communities and their Member States, of the one part, and the Republic of Tunisia, of the other part [1998] OJ L 97/2; Euro-Mediterranean Agreement establishing an Association with between the European Community and its Member States, of the one part, and the People's Democratic Republic of Lebanon, of the other part [2006] OJ L 143/2.
}

${ }^{11}$ COM (2003) 104 final, 11 April 2003, 4. 
rights (including non-justiciable principles). ${ }^{12}$ This was rather unusual since the EU refers to international standards in its contractual relations with third countries (see, for instance, human rights clauses of EU agreements). The Wider Europe Communication continues by including pluralism, civil liberties, and core labour standards, which are viewed as 'essential prerequisites for political stability, as well as for peaceful and sustained social and economic development' ${ }^{13}$ In addition, the Communication stresses the institutional aspect of democracy and human rights by emphasising the importance of 'strong democratic institutions' and 'the need to institutionalise respect for human rights'. ${ }^{14}$ After defining these core 'values', the Communication makes a judgment on the progress in political reform in the neighbourhood:

'Generally, the countries of the WNIS and Russia have taken steps towards establishing democracy and market institutions over the past 12 years. Yet political reform in the majority of the countries of the Mediterranean has not progressed as quickly as desired'. ${ }^{15}$

This judgment would have suggested at the time that the EU would be stricter in its approach towards values in the relations with the Southern neighbours than with the Western NIS.

The concept of 'shared values' is further emphasized in the 2004 ENP Strategy Paper:

'The privileged relationship with neighbours will build on mutual commitment to common values principally within the fields of the rule of law, good governance, the respect for human rights, including minority rights, the promotion of good neighbourly relations...'. ${ }^{16}$

\footnotetext{
${ }^{12}$ Charter of Fundamental Rights of the European Union [2010] OJ C83/389.

${ }^{13}$ COM (2003) 104 final, 11 April 2003, 7.

14 Ibid., 12.

15 Ibid., 7.

${ }^{16} \operatorname{COM}(2004) 373$ final, 12 May 2004, 3.
} 
While it would seem that democracy is replaced here with good governance, further on, the Strategy Paper gave the Commission monitoring powers with respect to 'the strengthening of democracy, the rule of law and respect for human rights' ${ }^{17}$ The ENP Strategy Paper most importantly specified the 'values' with reference to the future content of the APs. It was to include 'strengthening democracy and the rule of law, the reform of the judiciary and the fight against corruption and organised crime; respect of human rights and fundamental freedoms, including freedom of media and expression, rights of minorities and children, gender equality, trade union rights and other core labour standards, and the fight against the practice of torture and prevention of ill-treatment; support for the development of civil society; and co-operation with the International Criminal Court'. ${ }^{18}$ This appears to be an indicative list of priority actions, which includes general actions that can be shopped without any prioritisation. The ENP Strategy Paper also makes it clear that international standards will form the basis for the promotion of these values. These include UN human rights conventions, ECHR for those neighbours who are members of the Council of Europe, the UN Charter, the UDHR and, in relation to the South Caucasian countries, the OSCE. ${ }^{19}$ The 2006 Commission Communication on Strengthening the ENP did not add much to the understanding of the values and merely referred to their interlinked nature with the other areas of cooperation. ${ }^{20}$ This muted stance of the Communication might have been due to the fact that most of the bilateral APs were already in place by then.

In terms of the priority actions that reflect the EU values with each ENP country, the APs can be divided into two main groups: Egypt, Jordan, Lebanon, Morocco, Tunisia, Ukraine and Moldova in

\footnotetext{
17 Ibid., 10.

18 Ibid., 13.

${ }^{19}$ Ibid., 10-13.

${ }^{20}$ COM (2006) 726 final 4 December 2006, 3.
} 
one group and Georgia, Armenia and Azerbaijan in another. ${ }^{21}$ The APs for Egypt, Jordan, Lebanon, Morocco, Tunisia, Ukraine and Moldova can be grouped under a wider list of priority actions related to democracy and human rights. Despite the regional distinction and the presumption in the Wider Europe Communication that non-EU Mediterranean countries are lagging behind in their progress on political reform, a similar range of issues can be identified with a comparable intensity. ${ }^{22}$

Thus, the priority areas relevant for our discussion are usually divided under two headings: one, democracy and rule of law, and two, human rights and fundamental freedoms. ${ }^{23}$ The first heading mainly focuses on strengthening democratic institutions, often with an emphasis on free and fair elections, decentralisation, independence and efficiency of the judiciary, the functioning of the civil society, and the fight against corruption. The second heading refers to specific rights and freedoms, with a major emphasis on political rights, including freedom of association, media pluralism, prevention of torture, freedom of religion, women's and children's rights, social rights and labour standards.

Not all issues are equally reflected in all APs: for instance the APs of Egypt, Jordan, Lebanon, Morocco, Tunisia (Southern neighbors) have a stronger emphasis on women's rights, as well as fighting discrimination, racism and xenophobia. The Ukrainian and Moldovan APs have additional actions such as ensuring international justice related to the International Criminal Court. The APs in

\footnotetext{
${ }^{21}$ No APs have been established with Belarus, Algeria, Libya or Syria.

${ }^{22}$ Available on $<\underline{\text { http://eeas.europa.eu/enp/documents/action-plans/index_en.htm }>\text { accessed } 3 \text { June } 2015 .}$

23 Only the EU-Ukraine AP does not divide the actions under two headings.
} 
the first group were much criticised for being overly general in nature, with a lack of precision and poor benchmarking. ${ }^{24}$

The second group of APs (i.e. for the South Caucasian countries) is even more limited in its approach. Their priorities for political reform are structured around the issues of separation of powers, executive and judiciary, electoral reform, and guaranteeing basic rights. There are some significant omissions even from this shortened list. For instance, the Georgian AP largely omitted the issue of human rights and fundamental freedoms: the prohibition of torture is the only issue that featured on the human rights agenda of the Georgian AP. In the Azerbaijani AP, corruption featured in a separate area related to the improvement of the business climate, suggesting that this issue was being depoliticised. In the case of Armenia, the functioning of the national parliament and the political parties was omitted. Overall, these APs take a much more restrictive interpretation of EU values than the APs of the first group. ${ }^{25}$

There are two APs that stand out from the rest. The EU-Palestine AP should be distinguished because of the manner in which the issue of values is presented: prioritising the foundations of future state building in 'the rule of law and respect for human rights within a functioning deep

${ }^{24}$ On EU-Tunisia and EU-Jordan APs see Del Sarto and Schumacher, op.cit., 51, 56-62; on EU-Israel see W.T. Duma, 'Israel and the Palestinian Authority' in S. Blockmans and A. Lazowski (eds), The European Union and its Neighbours: A Legal Appraisal of the EU's Policies of Stabilisation, Partnership and Integration (TMC Asser Press 2006), 433-461, 457; R.A. Del Sarto, 'Wording and Meaning(s): EU-Israeli Political Cooperation according to the ENP Action Ilan' (2007) 12 Mediterranean Politics 59, 61-62; on EU-Morocco AP see K. Kausch, 'The European Union and Political Reform in Morocco' (2009) 14 Mediterranean Politics 165, 171; M. Emerson and G. Noutcheva, 'From Barcelona Process to Neighbourhood Policy: Assessments and Open Issues, CEPS Working Document', $2005,220$.

${ }^{25}$ For a more detailed analysis of the APs with South Caucasian countries, see Ghazaryan, op.cit., 130-149. 
democracy and with accountable institutions' ${ }^{26}$ Given the absence of statehood, it is understandable why no list of actions would be expected here, although there is a call for action in terms of political rights, women's and girl's rights. Israel's AP should also be viewed separately, although for a different reason. In this case, in distinction from the Aps considered before, there are no actions regarding state institutions and their practices as in the case of the first two groups, but rather both Israel and the EU would strive to fight racism, xenophobia, Islamophobia (Israel) and anti-Semitism (EU). ${ }^{27}$ It is the only AP where priorities are set for the EU as well. The impression that one draws from the content of the plan is that the values at the basis of the cooperation are perceived to be 'shared'.

It can therefore be concluded that the normative content set out in the ENP Strategy Paper has been most closely replicated in the APs for Ukraine, Moldova, Egypt, Jordan, Lebanon, Morocco, and Tunisia, although not in a fashion which can be seen as real benchmarking. This suggests a divide at this stage in the way the EU defined its values within the the Eastern neighbours, rather than a split between the East and the South.

The geographic split of neighbourhood policies and the projection of EU values after the Arab Spring

A few years after the establishment of the ENP, with the enterprise of certain proactive Member States, a regional split occurred in EU policies towards the neighbourhood with the initiation of the

\footnotetext{
26 Priority Objective 3 in the EU-Palestine AP.

${ }^{27}$ For a more detailed analysis of EU-Israel Action Plan see Del Sarto, op.cit..
} 
EaP in the East and a somewhat revamped Barcelona Process - the UfM in the South. ${ }^{28}$ To an extent, the geographic split marked the return to the original rationale of the ENP, that is to offer preferential relations to its Eastern neighbours. ${ }^{29}$ In its proposal for the EaP, the Commission envisaged that the new initiative would 'make a step change in relations with these partners' in comparison with the ENP that promised inter alia a free trade area. ${ }^{30}$

The EaP preserved the value rhetoric of the ENP, and promised a more intensified bilateral cooperation through association agreements. According to the EaP Communication 'a sufficient level of progress in terms of democracy, the rule of law and human rights, and in particular evidence that the electoral legislative framework and practice are in compliance with international standards, and full cooperation with the Council of Europe, OSCE/ODIHR and UN human rights bodies will be a precondition for starting negotiations and for deepening relations thereafter' ${ }^{31}$ In terms of the understanding of values, this suggested that, as far as the Eastern neighbours are concerned, not only international but also regional standards would be applied to them. The OSCE instruments had previously formed the basis of cooperation with the EU via the essential elements

28 Brussels European Council Conclusions, 19-20 June 2008, 19. For the discussion of the Member States' position at this stage see B. Van Vooren, 'The European Union as an International Actor and Progressive Experimentation in Its Neighbourhood' in P. Koutrakos (ed), European Foreign Policy: Legal and Political Perspectives (Edward Elgar Publishing, 2011) 147-171, 152-153.

29 E. Lannon and P. Van Elsuwege, 'The Eastern Partnership: Prospects of a New Regional Dimension within the ENP' in E. Lannon (ed), The European Neighbourhood Policy's Challenges (P.I.E. Peter Lang 2012) 285-322, 286.

${ }^{30}$ COM (2008) 823 final, 3 December 2008, 2.

${ }^{31}$ Ibid., 4. 
clauses in the Partnership and Cooperation Agreements (PCAs) ${ }^{32}$ Without dwelling on the problematic aspects of the application of the ENP conditionality, the start of the negotiations with most of the EaP countries demonstrated that the preconditions noted above in the Communication were mostly rhetorical. Despite significant shortcomings in the political reforms testified in the Commission's annual progress reports for each of the partners, negotiations had started with all EaP countries with the exception of Belarus.

The EaP also introduced a multilateral framework of cooperation for Eastern neighbours, which was expected to provide 'added value' to the new project. ${ }^{33}$ In this context, the novelty of the EaP was seen not in terms of the incentives or instruments on offer, but rather as the intention to enhance the relations between the Eastern partners themselves. ${ }^{34}$ The EaP was nonetheless aimed not only at introducing qualitative changes to the ENP: the initiative was to a certain extent directed at

32 PCA between the European Communities and their Member States, of the one part, and Russia, of the other [1997] OJ L327/3; PCA between the European Communities and their Member States, of the one part, and the Republic of Armenia, of the other [1999] OJ L239/3; PCA between the European Communities and their Member States, of the one part, and the Republic of Azerbaijan, of the other [1999] OJ L246/3; PCA between the European Communities and their Member States, of the one part, and the Republic of Georgia, of the other [1999] OJ L205/3; PCA between the European Communities and their Member States, of the one part, and the Republic of Moldova, of the other [1998] OJ L181/3; PCA between the European Communities and their Member States, of the one part, and Ukraine, of the other [1998] OJ L049/3.

33 For the Polish policy makers the EaP was to transform the Eastern neighbourhood based on the Visegrad accession experience; AK Cianciara, “"Eastern Partnership”- Opening a New Chapter of Polish Eastern Policy and the European Neighbourhood Policy?' No 4 June 2008, The Institute of Public Affairs, Warsaw, 3, 6.

34 Van Vooren, op.cit, 156. 
counterbalancing the Russian presence, since its launching was also linked to the August 2008 war in Georgia. ${ }^{35}$

On a structural level, the EaP introduced new forums for multilateral high-level meetings, which supports the suggestion that EaP takes the political association between the EU and its partners further than a 'classical association'. ${ }^{36}$ The conclusions of the first 2009 biannual Prague summit did not add much to the understanding of the values, simply making a recourse to the alignment of the relationship 'to the principles of international law and to fundamental values, including democracy, the rule of law and the respect for human rights and fundamental freedoms, as well as to market economy, sustainable development and good governance'. ${ }^{37}$ Any further elaboration of these concepts would have been expected of the new agreements.

Four thematic platforms have been established for multilateral cooperation in the form of an exchange of practices through meetings held twice a year for senior officials. The platforms established are on democracy, good governance and stability; economic integration and convergence with EU policies; energy security; and contacts between people. The thematic platform on democracy and good governance follows the Action Plan requirements mainly referring to the obligations the neighbouring states undertake in the Council of Europe or the OSCE. ${ }^{38}$

35 N. Popescu, 'ENP and EaP: Relevant for the South Caucasus?' in 'South Caucasus: 20 Years of Independence' (Friedrich Ebert Stiftung, 2011) 316-334, 327.

36 C. Hillion, and A. Mayhew, 'The Eastern Partnership- Something New or Window-dressing' SEI Working Paper No $109,2009,8-9$.

37 Eastern Partnership Prague Summit Declaration, 7 May 2009, 5.

${ }^{38}$ See Ghazaryan, op.cit. 
It can be argued that the real added value of the EaP for the purposes of EU democratic values is linked to the enhanced role of national parliaments and civil society. The parliamentary exchange was made possible through the Euronest parliamentary cooperation framework which, according to the ENP Commissioner, represents more than just another EaP structure: it is a tool to 'advance democratisation' via shared experiences between parliamentarians. ${ }^{39}$ The establishment of the civil society forum in 2009 , which convenes annually, is another important development within the EaP and compensates to some extent for the sidelined role of civil society within the ENP. The forum has established its own working groups, including groups devoted to democracy, good governance and stability.

The UfM was a qualitatively different initiative from the ENP as a mostly intergovernmental multilateral platform and with a wider membership than the EU Member States and the Southern neighbours. ${ }^{40}$ Driven by France, the aim of the UfM was to draw on the already existing multilateral project of the Barcelona Process, which had already promised a trade area for partner states. The Barcelona Process 'chapters', including those on political dialogue, were to continue to be the focus of the relations. ${ }^{41}$ The value rhetoric was preserved in the 2008 Paris Summit Declaration stressing the parties' commitment to strengthening democracy and political pluralism 'by the expansion of participation in political life and the embracing of all human rights and fundamental freedoms', 'full respect of democratic principles, human rights and fundamental freedoms, as enshrined in

39 S. Füle, European Commissioner for Enlargement and European Neighbourhood, Speech at the Euronest Parliamentary Assembly EuroNest Parliamentary Assembly Baku, Speech/12/256, 3 April 2012.

${ }^{40}$ It includes also current and potential candidate states (Montenegro, Albania, Bosnia and Herzegovina, Turkey) and other countries (Mauritania and Monaco); COM(2008) 319 final, 20 May 2008.

41 Economic Cooperation and Free Trade, and Human, Social and Cultural Dialogue, Migration, Social Integration, Justice and Security are the other chapters; ibid., 4. 
international human rights law, such as the promotion of economic, social, cultural, civil and political rights, strengthening the role of women in society, the respect of minorities, the fight against racism and xenophobia and the advancement of cultural dialogue and mutual understanding', ${ }^{42}$ However it became quite clear that political reform was not at the forefront of the new initiative, which was also characterised as being 'apolitical'43 or lacking 'reform objectives' ${ }^{44}$ Moreover, the UfM was criticised for foregoing political conditionality altogether. ${ }^{45}$ It also failed to establish parliamentary or civil society cooperation, ${ }^{46}$ in the same way as the EaP.

The EU's approach came under its own scrutiny shortly after the Arab Spring. The first reaction came in the form of a Partnership for Democracy and Shared Prosperity for the Southern neighbourhood. The new 'partnership' emphasised the need for joint efforts in political reform linking it to economic growth and development. ${ }^{47}$ The partnership for democracy was to focus on 'democratic transformation and institution-building, with a particular stress on fundamental freedoms, constitutional reforms, reform of the judiciary and the fight against corruption' and 'a stronger partnership with the people, with specific emphasis on support to civil society'. ${ }^{48}$ Although it can be suggested that 'constitutional reform' as such had not been mentioned hitherto in either ENP or UfM documents, all other components of political reform had already featured in ENP policy documents, as well as the APs with the Southern neighbours. An entry qualification was

\footnotetext{
42 Joint Declaration of the Paris Summit for the Mediterranean Paris, 13 July 2008, 10.

${ }^{43}$ Del Sarto and Schumacher, op.cit., 50.

44 R. Balfour, 'The Transformation of the Union for the Mediterranean' (2009) 14 Mediterranean Politics 99, 104.

45 J.C. Völkel, 'More for More, Less for Less - More or Less: A Critique of the EU's Arab Spring Response a la Cinderella’ (2014) 19 EFAR 263, 144.

${ }^{46}$ R. Gillespie, ‘A “Union for the Mediterranean” ... or for the EU? (2008) 13 Mediterranean Politics 277, 284.

${ }^{47}$ COM (2011) 200 final, 8 March 2011.

${ }^{48}$ Ibid, 3.
} 
established in 'a commitment to adequately monitored, free and fair elections', ${ }^{49}$ although without specifying what the 'entry' was entering into. Some have viewed the new partnership as having a sharper focus on the balance between the state and civil society, ${ }^{50}$ whereby 'expanding support to civil society' has been placed at the heart of democracy and institution building'. ${ }^{51}$ Such reorientation was particularly seen as 'a clear mea culpa on behalf of the EU'. ${ }^{52}$ Few years later, the Southern Neighbourhood Civil Society Forum was established holding its first session in $2014 .^{53}$

The revisionist approach is also seen in the Joint Communication of the Commission and the High Representative for Foreign Affairs reviewing the ENP in 2011. The review was initiated in 2010 prior to the turbulent events in the Southern neighbourhood, and it is not clear whether the revolutions left their mark on this policy document or whether the content of the review had already been established and translated into the Partnership for Democracy and Shared Prosperity. According to Gillespie:

\footnotetext{
${ }^{49}$ Ibid, 5.
}

${ }^{50}$ A. Teti, "The EU's First Response to the "Arab Spring": A Critical Discourse Analysis of the Partnership for Democracy and Shared Prosperity’ (2013) 17 Mediterranean Politics 266, 272-273, 276.

${ }^{51}$ COM (2011) 200 final, 8 March 2011.

52 'EU Action to Strengthen Respect for Human Rights and Democracy in the Process of Political Changes in the Middle East and North Africa', Directorate General for External Policies, European Parliament, 4 December 2012, 12 $<$ http://www.europarl.europa.eu/RegData/etudes/etudes/join/2012/457141/EXPO-DROI_ET(2012)457141_EN.pdf> accessed 3 June 2015.

53 'First EU- Southern Neighbourhood Civil Society Forum takes place in Brussels', Press Release, 28 April 2014, Brussels. 
'the existing policy review was extended so that adjustments could be made to the outcome. Essentially, the review brought proposals to make democratising reforms more central to the policy content of future ENP Action Plans', ${ }^{54}$

The revised ENP seemingly offers a closer partnership to build democracy, pursue economic development and manage migration. ${ }^{55}$ This outlook is based on a further differentiation — the socalled 'more for more approach', where it appears almost in an incentive-like role. ${ }^{56}$ However, the most prominent differentiation was not necessarily or exclusively linked to political reforms, but also to other internal or external political developments. ${ }^{57}$ The 'more for more approach' goes hand in hand with 'a new approach' in promoting democracy which was meant to signal a reinforced commitment to political reforms. ${ }^{58}$ On the one hand, it can be suggested that this was prompted by Article 8 TEU, inserted by the Lisbon Treaty. The 'new approach' is included in the first postLisbon revision of the ENP, which should be reflective the EU's commitments under Article 8 TEU. ${ }^{59}$ According to the latter provision, the 'Union shall develop a special relationship with neighbouring countries... founded on the values of the Union'. This suggests that the 'new approach' is mostly about underlining the importance of a commitment to these values, particularly

54 R. Gillespie, 'The UfM Found Wanting: European Responses to the Challenge of Regime Change in the Mediterranean' in F. Bicchi and R. Gillespie (eds), The Union for the Mediterranean (Routledge 2012) 211-223, 213.

55 COM (2011), 25 May 2011, 1.

${ }^{56}$ Ibid, 2, 8-9, 20-21; JOIN (2012) 14 final, 15 May 2012, 2-4.

57 P. Van Elsuwege, 'Variable Geometry in the European Neighbourhood Policy: The Principle of Differentiation and its Consequences' in E. Lannon (ed), The European Neighbourhood Policy's Challenges (College of Europe Studies, P.I.E. Peter Lang, 2012) 59-84, 66-67.

58 COM (2011), 25 May 2011, 2-3.

${ }^{59}$ For the analysis of article 8 TEU see P. Van Elsuwege and R. Petrov, 'Article 8 TEU: Towards a New Generation of Agreements with the Neighbouring Countries of the European Union?' (2011) 36 ELR 688 
when the substance of the commitments has not changed in practice. ${ }^{60}$ The 'new approach' therefore concerns the external rehabilitation of the EU's normative image in an attempt to distance itself from its past practice of cooperating with or even strengthening authoritarian regimes.

This 'new approach' is linked to the so called 'deep democracy' or 'deep and sustainable democracy'. ${ }^{61}$ This understanding of democracy follows the trend of merging the concepts of democracy, human rights and rule of law. It avoids commitments to core democratic values and instead focuses on the following formal criteria:

- $\quad$ 'free and fair elections;

- $\quad$ freedom of association, expression and assembly, and a free press and media;

- $\quad$ the rule of law administered by an independent judiciary and right to a fair trial;

- the fight against corruption;

- security and law enforcement sector reform (including the police) and the establishment of democratic control over armed and security forces' ${ }^{62}$

Most of these elements of 'deep democracy' were part of the policy's earlier approach, and do not add much specification to the content of the values, clarified at the previous stage of relations. However, such additions as the establishment of democratic control over armed and security forces or the right to a fair trial seem to be at odds with the rest of the elements which are rather general in character. These additions can be clearly explained within the revolutionary context of the Southern neighbours. The reference to 'sustainable democracy' suggests a shift towards a more inclusive understudying of human rights, inclusive of social and economic rights, as opposed to the previous

\footnotetext{
${ }^{60}$ Council Conclusions on the European Neighbourhood Policy, Foreign Affairs, 20 June 2011.

61 COM (2011), 25 May 2011, 3.

62 Ibid.
} 
practice of mainly focusing on political rights. However, in view of the following paragraph, this does not seem to be the case:

'Reform based on [the above] elements will not only strengthen democracy but help to create the conditions for sustainable and inclusive economic growth, stimulating trade and investment. They are the main benchmarks against which the EU will assess progress and adapt levels of support.' 63

It suggests that progress in institution-building and securing political freedoms is a prerequisite for economic development, rather than an actual insistence on securing social and economic rights for the peoples of the neighbouring countries. As part of a more general approach, the Council endorsed the Commission's report for democratic governance in December 2013 with an indication as to the EU's support for 'a rights based approach encompassing all human rights'. ${ }^{64}$ It should be also noted, that in line with the Partnership for Democracy and Shared Prosperity, the 2011 Communication revising the ENP also emphasized the importance of 'a partnership with society' with a major emphasis on civil society and its funding. ${ }^{65}$

The idea of 'deep democracy' has also been translated to the EaP framework with the 2011 and 2013 summit declarations, both making references to the commitment to 'deep and sustainable democracy' but without much elaboration. ${ }^{66}$ 'Deep and sustainable democracy' has also become part of the ENP Progress Reports since the post-Arab Spring ENP review. It is under this heading that the Commission evaluates the progress of each country in the area of political reforms,

\footnotetext{
63 Ibid., 4.

${ }^{64}$ Foreign Affairs (Development) Council Conclusions, 12 December 2013, para 2.

${ }^{65}$ COM (2011), 25 May 2011, 3-4.

66 Joint Declaration of the Eastern Partnership Summit, Warsaw, 29-30 September 2011, 1; Joint Declaration of the Eastern Partnership Summit, Vilnius, 28-29 November 2013, 2Eastern Partnership Vilnius Summit Declaration, 2.
} 
however the ever changing and patchy monitoring makes the idea of deep and sustainable democracy' seem somewhat fuzzy. ${ }^{67}$

Despite the coining of the new term 'deep' or 'deep and sustainable' democracy, no new mechanisms were established to achieve 'deep democracy', ${ }^{68}$ and neither did the 'new' approach make a difference in terms of the application of the ENP conditionality. Subsequent events have demonstrated that the 'new approach' did not last long and strict compliance with the values could be overlooked. For instance, after the overthrow of President Morsi in Egypt, no serious consequences followed, with the exception of the suspension of export licences to Egypt for any equipment that could be used for internal repression. ${ }^{69}$ Similarly in the East, AAs were signed with Ukraine while in political turmoil, as well as with Georgia and Moldova in rather hasty conditions despite the weaknesses in their political reform profiles. ${ }^{70}$

It can be concluded that there is no major rift between the understanding of values from South to the East. In fact the 'values' are general enough to spread the rhetoric to both flanks of the policy. Predominantly, however, they focus on institutional practices and political rights. There is however a stronger emphasis in the East on political reform, accompanied by a more meaningful mechanism (such as parliamentary and civil society cooperation), in comparison with the UfM following the initiation of the EaP. The events in the Southern neighbourhood required the EU to declare its reinforced commitment to its own values, while the 'new approach' of 'deep and sustainable'

\footnotetext{
${ }^{67}$ For criticism of Commission's monitoring see Ghazaryan, op. cit., 154-159.

68 M. Emerson, 'Review of the Review - of the European Neighbourhood Policy' CEPS Commentary, 8 June 2011, 4. $<$ http://www.ceps.eu/publications/review-review---european-neighbourhood-policy> accessed 3 June 2015.

${ }^{69}$ Foreign Affairs Council Conclusions, 21 August 2013, para 8.

${ }^{70} \operatorname{SWD}(2013) 90$ final, 20 March 2013, 4-8; SWD(2013) 80 final,. 5-8.
} 
democracy remained shallow in both flanks of the policy. This seeming parity, however, does not hold true when comparing the essential elements clauses between the Euro-Med Agreements and the Eastern Association Agreements (Eastern AAs).

\section{Human rights clauses as statements on EU values: Eastern AAs v Euro-Med Agreements ${ }^{71}$}

The human rights clauses in the Eastern AAs and the Euro-Med agreements have been analysed extensively elsewhere. ${ }^{72}$ The purpose of this section is a much narrower comparison between the essential elements clauses of these two groups of agreements. The Eastern AAs are not the first post-ENP agreements in the neighbourhood, as several Euro-Med Agreements were signed after the initiation of the ENP as noted above. However, the Eastern AAs are the first post-Lisbon agreements in the neighbourhood, which might suggest a more stringent standard in terms of the political commitments.

71 This section is based on N. Ghazaryan, 'A New Generation of Human Rights Clauses? The Case of Association Agreements in the Eastern Neighbourhood' (2015) 40 ELR 391.

${ }^{72}$ L Bartels, “A Legal Analysis of Human Rights Clauses in the European Union's Euro-Mediterranean Association Agreements" (2004) 9 Mediterranean Politics 368; Ghazaryan, ibid. 
The essential elements clauses constitute part of the so-called 'standard' human rights clauses in addition to a reference in the preamble and a provision on the suspension of the agreement. ${ }^{73} \mathrm{In}$ certain cases, a Joint Declaration accompanies the agreements linking the essential elements clause to the suspension mechanism. ${ }^{74}$ It is primarily the essential elements provision that creates the normative framework of the values that are promoted in both regions. Thus a comparison between the respective provisions of the Euro-Med Agreements and the Eastern AAs may reveal whether there is a distinct normative pattern as far as different geographic neighbourhoods are concerned.

Before turning to the essential elements clause, the preambular references should be noted as often they also contain indications as to the value dimension of the cooperation. The preambles of the Eastern AAs are much more vocal on 'value' issues than their Southern counterparts. Despite certain distinctions between the Eastern AAs, the rhetoric on common values in all three of them is more prevalent than in the Euro-Med Agreements. In the case of Georgia and Moldova, the values — that is democracy, human rights and fundamental freedoms, and the rule of law — are 'at the heart of political association and economic integration'75. However, in the case of Ukraine, they constitute the 'basis of the cooperation', whereas the values are spelled out in a rather detailed manner for a premable in order to include democratic principles, the rule of law, good governance,

${ }^{73}$ E. Riedel and M. Will, 'Human Rights Clauses in External Agreements of the EC' in P. Alston, The EU and Human Rights (OUP 1999) 723-754, 731-732; A Rosas, 'The European Union and Fundamental Rights/Human Rights' in C. Krause and M. Scheinin (eds), International Protection of Human Rights: A Textbook (Institute for Human Rights 2009) 443-474, 467; M. Bulterman, Human Rights in The Treaty Relations of the European Community: Real Virtues or Virtual Reality (Intersentia 2001), 157; L. Bartels, Human Rights Conditionality in the EU's International Agreements (OUP 2005) 23.

${ }^{74}$ For instance Euro-Med Agreement with Algeria.

75 Preambles of EU-Moldova and EU-Georgia Association Agreements. 
human rights and fundamental freedoms, including the rights of persons belonging to national minorities, non-discrimination of persons belonging to minorities, and respect for diversity and human dignity'. ${ }^{76}$ They are found in the previous policies and the commitments made by the parties in the past.

More toned down and narrower references are found in the Euro-Med agreements. Here the values form the 'basis of cooperation' which include human rights, political and economic freedoms ${ }^{77}$ and in some cases also democratic principles. ${ }^{78}$ Furthermore, already the preambles of the Eastern AAs indicate a more extensive scope of obligations. In fact, they make a reference to the UN Charter, OSCE documents, UDHR, and ECHR as opposed to only the UN Charter in the case of the EuroMed Agreements.

As regards the essential elements themselves, the Eastern AAs are more onerous both in terms of the elements considered as essential, as well as the international standards that form their basis. In so far as the essential elements are concerned, they usually include respect for human rights and democracy. The scope of the essential elements can be also expanded to include references to the rule of law as in the case of the EU contractual relations with certain countries in the Balkans. ${ }^{79}$ At times the rule of law is not part of the essential element clause, but is included among the areas of

\footnotetext{
${ }^{76}$ Preamble of EU-Ukraine Association Agreement.

${ }^{77}$ Euro-Meg Agreement with Algeria, Euro-Med Agreement with Morocco, Euro-Med Agreement with Tunisia.

${ }^{78}$ Euro-Med Agreement with Egypt, Euro-Med with Israel (human rights and democracy, no reference to political and economic freedoms here), Euro-Med Agreement with Jordan.

79 See for instance art. 2, Stabilisation and Association Agreement between the European Communities and their Member States, of the one part, and the Republic of Albania, of the other part [2009] OJ L 107/166.
} 
cooperation. ${ }^{80}$ The PCAs with Georgia, Armenia and Azerbaijan also included respect for the principles of international law, explained with reference to the outstanding conflicts in the region. ${ }^{81}$ In addition, the essential element provision of the PCAs and the SAA with the Balkan states include the principles of market economy, for which a rationale has been found in the communist past of the countries concerned..$^{82}$

The widening of the scope of these provisions has been criticised as discrediting the 'essential' nature of these elements, since the longer the list, the less essential its elements. ${ }^{83}$ However, this does not diminish the 'essential' status of these provisions in terms of their function. ${ }^{84}$ On the other hand, it can be argued that the scope of the essential element clauses is the widest in the neighbourhood. The Euro-Med agreements that were signed both before and after the ENP make no references to the rule of law, principles of international law or the market economy, and instead are limited to human rights — at times 'fundamental human rights' — and democratic principles. ${ }^{85}$

In contrast, the Eastern AAs include 'democratic principles, human rights and fundamental freedoms', offering a more nuanced approach by including 'human rights and fundamental

80 M. Cremona, 'The European Neighbourhood Policy: Legal and Institutional Issues', Centre on Democracy, Development and the Rule of Law, Working Papers, No 25, 2 November 2004, 20; See also P. Van Elsuwege in this volume.

${ }^{81}$ See for instance common art. 2 PCAs with Armenia, Georgia, and Azerbaijan, Riedel and Will, op.cit., 743.

${ }^{82}$ E. Fierro, The EU's Approach to Human Rights Conditionality in Practice (Hague: Martinus Nijhoff, 2003), 235.

${ }^{83}$ Bulterman, op.cit., 161.

${ }^{84}$ Ghazaryan, A New Generation of Human Rights Clauses, op.cit., 399-400.

${ }^{85}$ Arts. 2 of Euro-Med Agreement with Algeria; Euro-Med Agreement with Egypt; Euro-Med Agreement with Jordan; Euro-Med Agreement with Israel, Euro-Med Agreement with Lebanon; Euro-Med Agreement with Morocco; Euro-Med Agreement with Tunisia. 
freedoms' ${ }^{86}$ In addition, a new element on countering the proliferation of weapons of mass destruction, related materials and their means of delivery is also included as an essential element in line with the 2003 Council Common Position on non-proliferation. ${ }^{87}$ By contrast, none of the EuroMed agreements concluded after the ENP initiation and the adoption of the relevant Council Position have a similar provision. In other agreements, the issue of non-proliferation surfaced only as part of the political dialogue. ${ }^{88}$

An interesting variation lies with the rule of law and certain other new elements, which are exclusive to the Eastern AAs among the ENP agreements. Ordinarily no further explanations are provided as to the meaning of the rule of law, ${ }^{89}$ which appears to be the case with the Ukrainian clause. This provision is further stretched to include the principles of sovereignty and territorial integrity, inviolability of borders and independence as essential elements. This can be explained with reference to the political situation in Ukraine, in view of the Russian annexation of Crimea, and can therefore be seen as an expression by the EU of its support for Ukraine. ${ }^{90}$ The EU has been

\footnotetext{
${ }^{86}$ Art. 2 of EU-Ukraine AA, EU-Moldova AA, EU-Georgia AA.

87 Council Common Position 2003/805/CFSP of 17 November 2003 on the universalisation and reinforcement of
} multilateral agreements in the field of non-proliferation of weapons of mass destruction and means of delivery [2003] OJ L 302/34; M. Cremona, 'Values in EU Foreign Policy' in M. Evans and P. Koutrakos (eds), Beyond the Established Legal Orders: Policy Interconnections between the EU and the Rest of the World (Hart Publishing 2011) 275-315, 305.

88 See arts. 4-5 of Euro-Med Agreement with Syria, not signed. Council of the European Union <http:// register.consilium.europa.eu/doc/srv?1=EN\&f=ST\%209921\%202009\%20INIT $>$ accessed 3 June 2015.

${ }^{89}$ Pech finds exceptions in the Cotonou agreement, L Pech, 'Promoting the Rule of Law Abroad: On the EU's Limited Contribution to the Shaping of an International Understanding of the Rule of Law' in D. Kochenov and F. Amtenbrink (eds), The European Union's Shaping of the International Legal Order (CUP 2013) 108-129, 114.

${ }^{90}$ Following a referendum in Crimea on 16 of March on the issue of acceding to Russia, an Accession Treaty was signed to include the Republic of Crimea and Sevastopol as part of the Russian Federation on 18th of March 2014. 
unequivocal in its condemnation of the illegal referendum on independence and the subsequent annexation of the peninsula. ${ }^{91}$

However, in the Georgian and the Moldovan AAs, the rule of law as such does not constitute part of the essential element clause and is stipulated in a different paragraph of the same article framed in a language of 'reaffirming respect' for the rule of law and good governance. ${ }^{92}$ Unlike the Ukrainian AA, the Georgian and the Moldovan AAs provide for further clarifications of the principle of the rule of law with reference to partners' international obligations in the UN, the Council of Europe and the OSCE. Although in the case of Moldova, this is not specified within any particular context, the Georgian AA ties the rule of law to a wider international and national context. In Art. 2(2) the rule of law is linked to the principles of sovereignty and territorial integrity, inviolability of borders and independence, which therefore do not feature as essential elements - as in the case of Ukraine but serve merely as an indicator to the meaning of the rule of law. While including the principles of sovereignty and territorial integrity, inviolability of borders and independence within the general principles of cooperation can similarly be explained by the presence of frozen conflicts, their exclusion from the essential element clause might be related to a less pressing political situation around the Abkhazian and South Ossetian conflicts. In addition, the commitment to the rule of law is further specified with reference to good governance, the fight against corruption, organised crime, terrorism etc. ${ }^{93}$

\footnotetext{
${ }^{91}$ Foreign Affairs Council Conclusions, 17 March 2014, para. 1; European Council Conclusions, 20-21 March, para. 29.

${ }^{92}$ Art. 2(3) of EU- Moldova AA.

${ }^{93}$ Art. 2(3) and (4) of EU-Georgia AA.
} 
The Moldovan and Georgian agreements, unlike their Ukrainian counterpart, provide for the commitment towards the principles of a free market economy, sustainable development and effective multilateralism within the same article as the essential element provision, albeit in a different paragraph. Although the principle of a free market economy has previously been referred to in the PCA and SAA essential elements clauses, ${ }^{94}$ the reference to sustainable development and effective multilateralism is new. Both the PCAs and the SAAs establish the principles of a market economy as part of the essential element clause, as reflected in the CSCE Bonn document. ${ }^{95}$ This document mentions the objectives and endeavours of the participants to achieve 'sustainable economic growth', which can be compared to the principle of sustainable development. The reference to effective multilateralism suggests that it potentially refers to the WTO membership of the parties concerned. Ultimately, these principles are not part of the essential elements clause as such, and similarly to the rule of law, only constitute part of the general provisions which reiterate the commitments of the parties, but do not have the same status as essential elements.

In comparison, the Ukrainian AA provides for a separate article within the general provisions, emphasising the importance of the principle of a free market economy, the rule of law, good governance, the fight against corruption, trans-national organised crime and terrorism, the promotion of sustainable development and effective multilateralism. ${ }^{96}$ Thus in all three cases, the general principles have been expanded beyond the essential elements clause, hence making a distinction between the 'hard core common values' and 'other general principles' that are important

\footnotetext{
94 The Euro-Med agreements do not make reference to the principle of market economy.

95 See for instance art. 2 in Ukraine PCA, Moldova PCA; art. 2 in Stabilisation and Association Agreement with Albania; Stabilisation and Association Agreement between the European Communities and their Member States of the one part, and the Republic of Serbia, of the other part [2013] OJ L278/16.
}

${ }^{96}$ Art. 3 of EU-Ukraine AA. 
to the parties. ${ }^{97}$ However, the variation between the Ukrainian AA and the Georgian and Moldovan AAs demonstrates the flexible and rather arbitrary nature of this distinction.

In terms of the normative framework, human rights clauses often contain references to certain international instruments. The insertion of such references opposes the so-called tout court approach, which does not provide for additional information. ${ }^{98}$ The latter is therefore characterised by a higher level of abstraction, which creates flexibility on the part of the party with more leverage to determine the meaning of the provision. ${ }^{99}$ The most prevalent practice in the standard human rights clauses is the reference to the Universal Declaration of Human Rights (UDHR), viewed as testimony to the universality of the principles to which the parties have to adhere. ${ }^{100}$ The presumption of the universality of the norms here to a certain extent reflects the EU constitutional framework, starting from art. 11(1) EU and continuing in art. 21(1) and 21(2)(c) TEU.

97 G. van der Loo and P. van Elsuwege and R. Petrov, "The EU-Ukraine Association Agreement: Assessment of an Innovative Legal Instrument”, EUI Working Papers No.9 (2014),13.

${ }^{98}$ Fierro, op.cit., 234, 231.

99 P. Leino, 'The Journey towards All that is Good and Beautiful: Human Rights and "Common Values" as Guiding Principles of EU Foreign Relations Law' in M. Cremona and B. de Witte (eds), EU Foreign Relations Law: Constitutional Fundamentals (Hart Publishing 2008), 279.

100 A. Rosas, 'The European Union and International Human Rights Instruments' in V. Kronenberger (ed), The European Union and the International Legal Order: Discord or Harmony? (TMC. Asser Press 2011) 53-67, 61; B. de Witte, 'The EU and the International Legal Order: The Case of Human Rights' in M. Evans and P. Koutrakos (eds), Beyond the Established Legal Orders. Policy Interconnections between the EU and the Rest of the World (Hart 2011) $127-147,141-142$. 
While the tout court approach can be found in some Euro-Med agreements, ${ }^{101}$ in others the only international instrument referred to is the UDHR, ${ }^{102}$ which is viewed as a 'compromise', opting for the middle ground between the tout court approach and a very 'loaded' content. ${ }^{103}$ This aspect of the Euro-Med agreements is in stark contrast with the practice found in the Eastern AAs, where the UDHR is supplemented by the European Convention of Human Rights (ECHR), the Helsinki Final Act and the Paris Charter. Here, the regional instruments have been used to define the normative framework of the essential elements, which would not have been applicable to the Southern neighbours. What is surprising however is that in terms of the reference to the ECHR, the Eastern AAs appear to be more onerous than certain SAA candidate countries. ${ }^{104}$

Although as part of customary international law, the UDHR would be binding for members of international community, ${ }^{105}$ no other document cited in the essential elements clause is directly binding on the parties. It has been suggested that the reliance on non-binding instruments is 'an indirect strengthening of international human rights standards, as they add another enforcement mechanism to otherwise "toothless" international supervisory bodies'.106 This dynamic is different as far as the ECHR is concerned: it is the only instrument to create directly binding legal obligations for the countries concerned, whereby they risk losing membership of the Council of Europe. In this

\footnotetext{
${ }^{101}$ Art. 2 of Euro-Med Agreement with Israel, Euro-Med Agreement with Tunisia.

102 References to UDHR for instance can be found in Euro-Med Agreements with Algeria, Egypt, Jordan, Morocco.

103 Fierro, op.cit, 237.

104 Ghazaryan, A New Generation of Human Rights Clauses, op.cit., 398.

105 De Witte, op. cit., 141-142.

${ }^{106}$ F. Hoffmeister, 'The Contribution of EU Practice to International Law' in M. Cremona (ed), Developments in EU External Relations Law (OUP 2008) 37-127, 114.
} 
respect, it is possible to conclude that the essential elements clause of the Eastern AAs is the strictest in the neighbourhood.

It should be noted that the essential elements clauses in the Eastern AAs have a more clearly defined normative scope. However, some view the enhancement of the list of the international instruments negatively, claiming that the more instruments are referred to in the provision, the more uncertain the exact standard promoted. ${ }^{107}$ Others argue for an open-ended list of human rights instruments, whereby including a phrase on 'other human rights instruments' could be considered as a positive evolution, which would allow the normative basis of the human rights clauses to be updated in line with the emerging practice. ${ }^{108}$ Here a distinction should be made between the Ukrainian AA and the Georgian and Moldovan AAs . In the latter case, the list of acts appears to be exhaustive, while in the former, the provision refers to 'other relevant human rights instruments' thus rendering the list open ended.

None of the agreements actually refer to the EU human/fundamental rights standards as general principles of law or as established in the Charter of Fundamental Rights. Presumably, this is to steer away from accusations of imposing EU standards on outsiders, and thereby adhering to the universality of the values promoted.

\footnotetext{
${ }^{107}$ Nogueras and Martinez as cited in A. Williams, EU Human Rights Policies: A Study in Irony (OUP 2004), 41.

${ }^{108}$ Art. 1, Framework Agreement between the European Union and its Member States, of the one part, and the Republic of Korea, on the other part [2013] OJ L20; L. Bartels, 'The European Parliament's Role in Relation to Human Rights in Trade and Investment Agreements' (2014), 9, 14-15.
} 
Thus, judging from the essential elements provisions only, the human rights clauses in the Eastern AAs reveal a more enhanced approach in terms of the basis of cooperation that stretches beyond democratic principles and human rights as essential elements. They also show much wider international standards defining those essential elements where the European regional instruments feature heavily. It clearly demonstrates the political and geographic proximity of the Eastern European — neighbours of the EU.

\section{Conclusions}

The initial ENP policy documents suggested a common reference point as far as 'values' were concerned. The detailing of what constitutes values in the first ENP bilateral documents, the APs, demonstrated that there is no East/South division, but rather one between the Western NIS and Southern neighbours on the one hand, and the South Caucasian countries on the other. In this respect, the Israeli and the Palestinian counterparts stand on their own for specific reasons: Palestine due to an absence of statehood, Israel due to the perception of sharedness of values with a limited number of actions prescribed for both the EU and Israel. Nevertheless, all APs in combination confirm the fluid nature of the concept of values, which allows for much generalisation.

As far as the regional policy division is concerned, the 'value' rhetoric, although preserved on both sides, was nevertheless more in tune with the reality of the EaP than the UfM. The ENP revisions, which to a certain extent coincided with the response to the Arab Spring, led to the EU's acknowledgement of its past failures. In response, 'a new approach' focusing on 'more for more' and 'deep democracy' was set up to help the EU rectify its record. However, the 'new' approach has proven to be more of a label rather than a qualitatively different framework or method of 'sharing' 
EU values. The 'deep democracy' rhetoric has also been translated to the Eastern flank of the policy, although in a similar meaningless fashion. A noticeable addition to the revision of the policy was the acknowledgement of the importance of engagement with the civil society in neighbouring countries.

The most prominent distinction between the two regions, however, concerns the essential elements clauses of the Eastern AAs and the Euro-Med Agreements. The clauses of the Eastern AAs are wider in scope, and therefore much more onerous, not only in terms of the essential elements themselves, but also the normative internal framework underpinning it. This can be justified by the geographic and political proximity of the Eastern neighbours. The Eastern AAs acknowledge the 'European' nature of the relevant countries: although membership is not currently on the cards, the qualification of these countries as 'European' will help to keep the speculation alive.

Word Count: 9.523 